\title{
MENGOPTIMALKAN POTENSI SUMBER DAYA ALAM DENGAN MENINGKATKAN KUALITAS SUMBER DAYA MANUSIA MELALUI KEPEDULIAN LINGKUNGAN DI KAMPUNG BABAKAN INPRES DESA CEMPLANG
}

\author{
Muhyani ${ }^{1}$, Siti Rosada, Widya Sartika ${ }^{2}$ \\ muhyani@fai.uika-bogor.ac.id
}

Dosen Fakultas Agama Islam ${ }^{1}$, Mahasiswa KKN Kelompok 21 Tahun $2018^{2}$

\begin{abstract}
ABSTRAK
Sumber Daya Alam (SDA) yaitu segala sesuatu yang berasal dari alam yang dapat digunakan untuk memenuhi kebutuhan hidup manusia, sedangkan Sumber Daya Manusia (SDM) yaitu penduduk yang telah memasuki usia angkatan kerja baik yang belum bekerja maupun yang sudah bekerja. Adapun perilaku peduli lingkungan adalah perilaku yang secara sadar berupaya untuk mengurangi dampak negatif yang disebabkan oleh aktivitas seseorang terhadap lingkungan. Desa Cempalang Kecamatan Cibungbulang memiliki potensi yang perlu dikembangkan secara optimal. Potensi tersebut diantaranya yaitu potensi dalam bidang pertanian, yang mana dapat meningkatakan perekonomian daerah tersebut. Selain itu, pendidikan, kesehatan, serta hukum dan/ kemasyarakatan juga perlu dioptimalkan untuk meningkatkan kualitas sumber daya manusia di daerah tersebut. Tujuan program KKN ini adalah mengembangkan potensi sumber daya alam dan meningkatkan kualitas sumber daya manusia dalam berbagai bidang, diantaranya yaitu bidang pendidikan, agama, kesehatan, ekonomi, hukum dan/ kemasyarakatan, serta meningkatkan kepedulian masyarakat terhadap lingkungan. Adapun metode yang digunakan yaitu wawancara, observasi, dan dokumentasi. Realisasi program Kuliah Kerja Nyata secara umum terdiri dari 6 proyek, yaitu Proyek Sekolah Bersih; Proyek Sekolah Hijau (Green School); Proyek Pemanfaat Sampah; Proyek Pemanfaat Lahan dan Penghijauan Lahan; Proyek Penggerakan Pemuda; dan Proyek Pemakmuran Masjid.
\end{abstract}

\section{Kata kunci : Sumber Daya Alam, Sumber Daya Manusia, Kepedulian Lingkungan}

\section{PENDAHULUAN}

Perkembangan zaman yang cepat dengan didukung oleh kemajuan teknologi dan banyaknya budaya asing yang masuk, membuat kita dituntut untuk dapat berkembang agar tidak tertinggal, yang mana perkembangan tersebut diharapkan dapat memberikan dampak yang positif. Tetapi, fakta yang terjadi di masyarakat adalah perkembangan zaman yang semakin maju, bertolak belakang dengan kepedulian masyarakat terhadap lingkungan. Kurangnya atau hilangnya kepedulian terhadap lingkungan dapat dilihat dari kurangnya kebersihan lingkungan, seperti banyaknya sampah yang menumpuk pada aliran air; selain itu, masyarakat belum dapat memanfaatkan secara optimal potensi sumber daya alam yang tersedia, seperti banyaknya lahan kosong yang kurang dimanfaatkan 
sehingga terbengkalai; serta kurangnya interaksi dalam masyarakat, yang seharusnya dapat didukung oleh keaktifan dalam menyelenggarakan kegiatan berbasis kepedulian lingkungan sehingga dapat menjadi wadah kegiatan dalam mengoptimalkan potensi sumber daya alam dan meningkatkan kualitas sumber daya manusia. Dalam situs Wikipedia (2018) dipaparkan mengenai sumber daya alam (SDA) yaitu segala sesuatu yang berasal dari alam yang dapat digunakan untuk memenuhi kebutuhan hidup manusia, sedangkan sumber daya manusia (SDM) yaitu penduduk yang telah memasuki usia angkatan kerja baik yang belum bekerja maupun yang sudang bekerja. Adapun perilaku peduli lingkungan menurut Kollmus dan Agyeman (2002) dalam Akhtar (2014) adalah perilaku yang secara sadar berupaya untuk mengurangi dampak negatif yang disebabkan oleh aktivitas seseorang terhadap lingkungan. Desa Cempalang Kecamatan Cibungbulang memiliki potensi yang perlu dikembangkan secara optimal. Potensi tersebut diantaranya yaitu potensi dalam bidang pertanian, yang mana dapat meningkatakan perekonomian daerah tersebut. Selain itu, pendidikan, kesehatan, serta hukum dan/ kemasyarakatan juga perlu dioptimalkan untuk meningkatkan kualitas sumber daya manusia di daerah tersebut.

Tujuan Program KKN ini adalah mengembangkan potensi sumber daya alam dan meningkatkan kualitas sumber daya manusia dalam berbagai bidang, diantaranya yaitu bidang pendidikan, agama, kesehatan, ekonomi, hukum dan/ kemasyarakatan, serta meningkatkan kepedulian masyarakat terhadap lingkungan. Adapun manfaat kegiatan ini adalah sebagai sarana yang dapat mendukung pelaksanaan pengembangan sumber daya alam dan peningkatan kualitas sumber daya manusia dalam mengoptimalkan potensi yang tersedia, serta menumbuhkan ataupun meningkatkan kepedulian masyarakat terhadap lingkungan. Kegiatan ini diharapkan dapat menjadi sarana bagi semua anggota untuk berperan secara aktif dalam membantu memecahkan permasalahan yang terjadi di masyarakat.

\section{Kondisi Geografis}

Desa Cemplang merupakan sebuah Desa yang terletak di Kecamatan Cibungbulang Kabupaten Bogor, dengan luas wilayah 223,6605 $\mathrm{Ha}$, dengan ketinggian diatas permukaan laut $200 \mathrm{M}$ dan tinggi curah hujan $1700 \mathrm{M}^{3}$. Desa Cemplang terbagi dalam 3 Dusun, 7 Rukun Warga (RW) dan 30 Rukun Tetangga (RT). Batas-batas Desa Cemplang yaitu arah Utara berbatasan dengan Desa Dukuh dan Galuga; arah Timur berbatasan dengan Desa Cimanggu II dan Cibatok I; arah Selatan berbatasan dengan Desa Sukamaju; dan arah Barat berbatasan dengan Desa Leuwimekar. Jumlah Penduduk Desa Cemplang sampai akhir Desember 2011 tercatat sebanyak 8.550 jiwa, terdiri dari laki-laki sebanyak 377 jiwa, Perempuan sebanyak 4.186 jiwa, dan jumlah kepala keluarga 2.025 KK (Profil Desa Cemplang, 2017).

\section{Kondisi Perekonomian}

Kondisi potensi sumber daya alam dalam sektor pertanian yang terdapat di desa cemplang belum dapat dioptimalkan dengan baik. Hal tersebut dapat dilihat pada data profil desa cemplang (2017) mata pencarian penduduk Desa Cemplang yang bekerja dalam sektor pertanian relatif lebih sedikit jika dibandingkan dengan pekerjaan lainnya seperti pedagang. 
Adapun mata pencaharian penduduk Desa

Cemplang dapat dilihat pada tabel berikut :

\begin{tabular}{|c|c|c|}
\hline No & Jenis Pekerjaan & Jumlah \\
\hline 1 & Petani dan Buruh Tani & 251 \\
\hline 2 & Pedagang & 412 \\
\hline 3 & Pegawai Negeri Sipil & 39 \\
\hline 4 & TNI/Porli & 7 \\
\hline 5 & Pensiunan/purnawirawan & 16 \\
\hline 6 & Swasta & 131 \\
\hline 7 & Buruh pabrik & 148 \\
\hline 8 & Pengrajin & 5 \\
\hline 9 & Tukang bangunan & 35 \\
\hline 10 & Penjahit & 9 \\
\hline 11 & Tukang las & 2 \\
\hline 12 & Tukang ojek & 96 \\
\hline 13 & Bengkel & 6 \\
\hline 14 & Supir angkutan & 32 \\
\hline 15 & Lain-lain & 859 \\
\hline
\end{tabular}

\section{Kondisi Bidang Pendidikan, Keagamaan,} dan Kesehatan

Fasilitas pendidikan yang terdapat di Desa Cemplang diantaranya yaitu RA/TK Al-Qur'an berjumlah 5, Madrasah Ibtidaiyah berjumlah 1. Pondok pesantren berjumlah 9, dan majeli ta'lim berjumlah 14. Di Desa Cemplang tidak memiliki MTs dan MAN. Desa cemplang lebih banyak memiliki Mushola dari pada masjid. Adapun jumlah mushola yaitu 19 dan masjid 9. Sedangkan untuk tempat ibadah agama lainnya tidak ada. Selain bidang agama, di desa cemplang terdapat Puskesmas / Polindes berjumlah 1; Bidan Praktik berjumlah 1; Dokter Praktik berjumlah 5 , posyandu berjumlah 7 ; dan apotik/ tokok obat berjumlah 7 .

\section{METODOLOGI}

Menurut Sugiyono (2016 : 2) metode penelitian adalah cara ilmiah yang digunakan untuk mendapatkan data dengan tujuan dan kegunaan tertentu. metode yang digunakan untuk mengumpulkan data dalam kegiatan Kuliah Kerja Nyata (KKN) yaitu wawancara, observasi, dan dokumentasi. Wawancara digunakan sebagai teknik untuk mengumpulkan data ketika peneliti akan melakukan studi pendahuluan untuk menemukan permasalahan yang akan diteliti (Sugiyonio, 2016 : 2). Observasi digunakan apabila peneliti ingn mendapatkan data yang berkenaan dengan perilaku manusia, proses kerja, gejalagejala alam, yang mana observasi tidak terlepas pada manusia, melainkan pada objek alam lainnya (Sugiyonio, 2016 : 145). Adapun metode dokumentasi yaitu catatan peristiwa baik berbentuk tulisan, gambar (foto), film atau karya monumental, dan sebagainya (Sugiyono, 2016: 240) .

\section{Evaluasi Kegiatan Kuliah Kerja Nyata $($ KKN)}

Evaluasi merupakan gambaran umum dari setiap tahapan pelaksanaan kegiatan yang terdiri dari evaluasi proses dan evaluasi akhir. Evaluasi proses dilaksanakan selama proses kegiatan KKN berlangsung, baik pada waktu perecanaan maupun pada waktu tahapan kegiatan; adapun evaluasi akhir dilaksanakan dikahir kegiatan KKN yang mencangkup tingkat pencapaian, faktor pendukung/hambatan, efesiensi, dan efektifitas program dan dampak yang ditimbulkan setelah pelaksanaan KKN (LPPM, 2018 : 65). 


\section{REALIASI PROGRAM}

Program kegiatan KKN ini terdiri dari beberapa bidang yang mana secara garis besar program tersebut mencakup 6 proyek, yaitu Proyek Sekolah Bersih; Proyek Sekolah Hijau (Green School); Proyek Pemanfaat Sampah; Proyek Pemanfaat Lahan dan Penghijauan Lahan; Proyek Penggerakan Pemuda; dan Proyek Pemakmuran Masjid. Adapun rincian program sebagai berikut:

\section{Program Fisik dan Non-Fisik}

\section{Bidang Pendidikan}
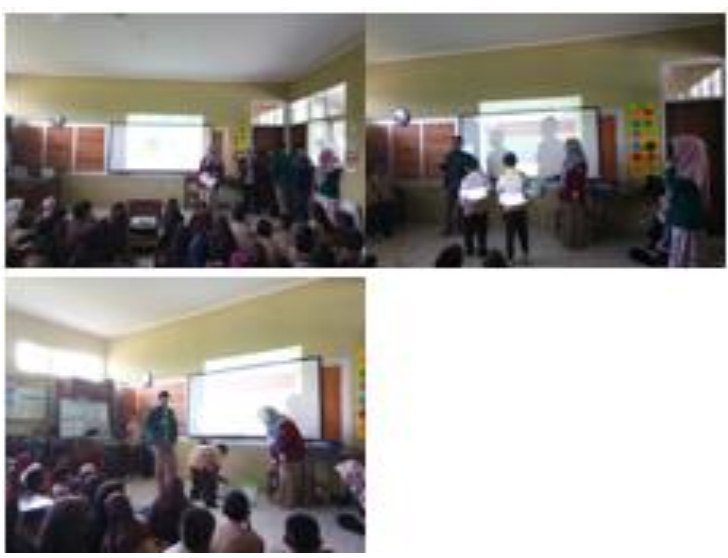

a. Penyuluhan Pentingnya Menjaga Lingkungan Kepada Siswa/Siswi Sekolah Dasar dan Demo Memilah Sampah Organik Dan An-Organik

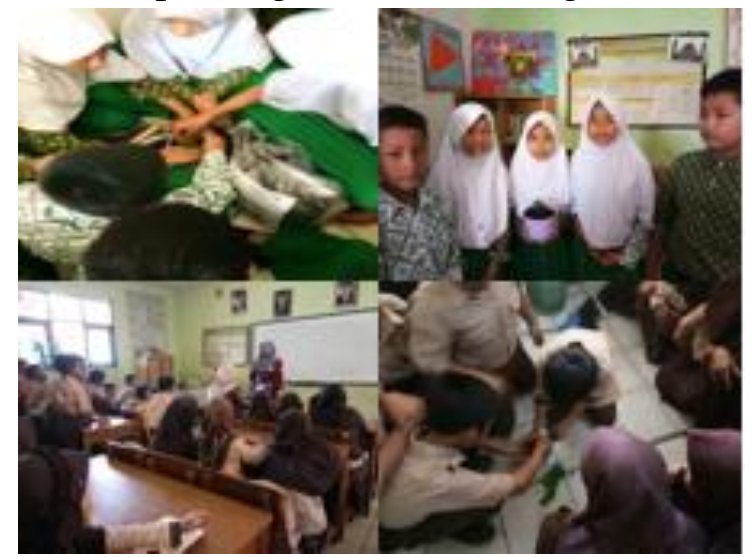

b. Penyuluhan Bercocok Tanam Pada Siswa/Siswi; dan Demo Menanam Tumbuhan serta Penghijauan Di Lingkungan Sekolah. (Untuk
Mendukung Proyek Sekolah Hijau / Green School)

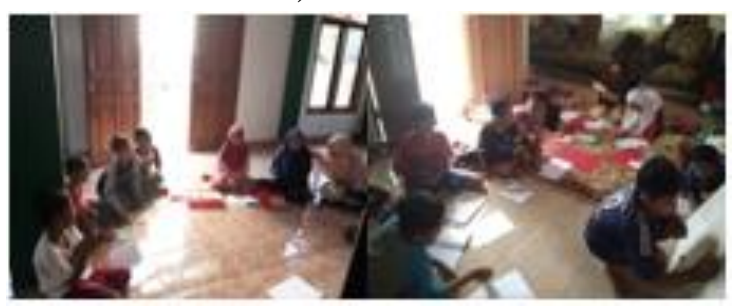

c. Pemberian Bimbingan Belajar Untuk Siswa Sekolah Dasar

\section{Bidang Agama}

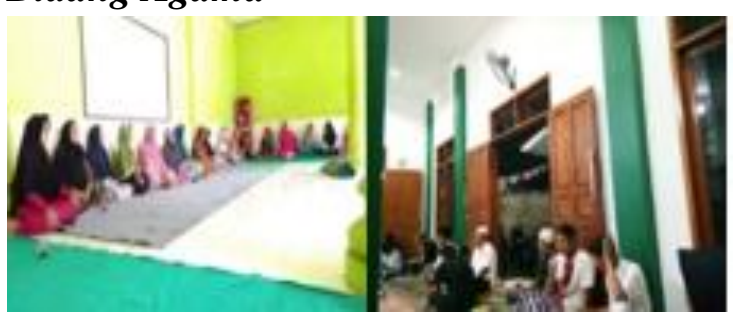

a. Penyuluhan

Pemakmuran

Masjid/Mushola Kepada Masyarakat, dan Pengajian Remaja, Dan Orang Tua

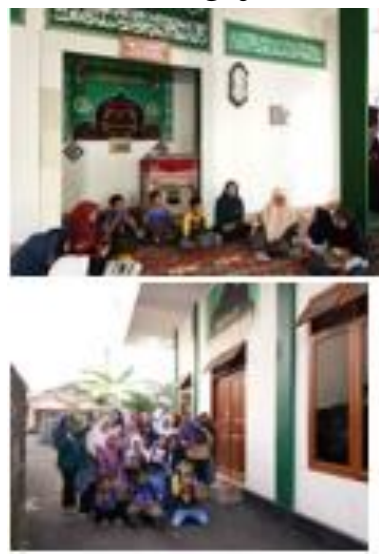

b. Pengajaran TPA (Taman Pendidikan Al-Qur'an)
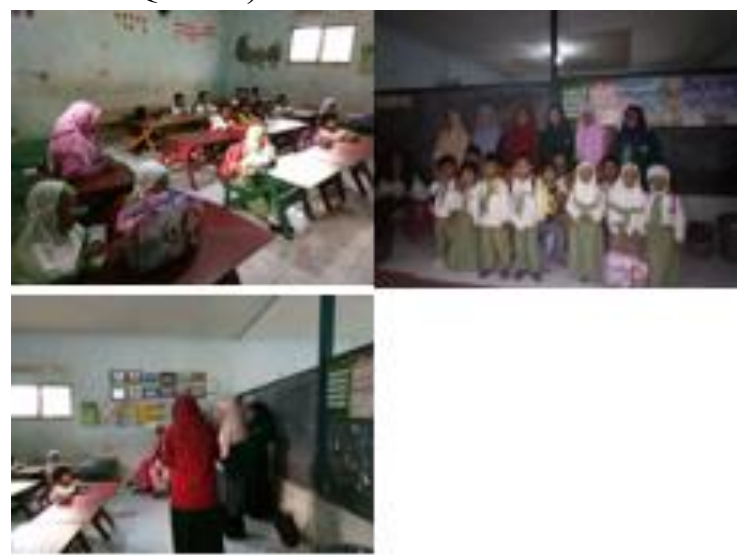

c. Pengajaran TPQ untuk anak Usia Dini. 


\section{Bidang Kesehatan}

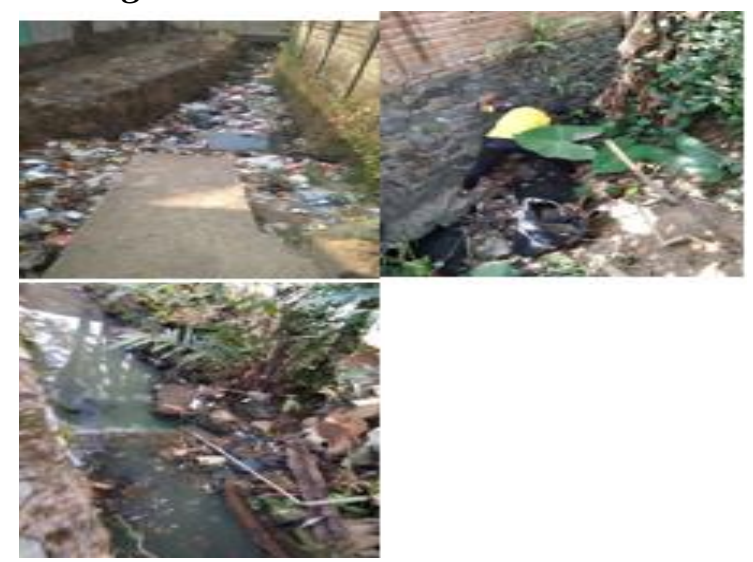

a. Penyuluhan Kebersihan, Kesehatan Dan Penghijauan Lingkungan Kepada Masyarakat, dan Kerja Bakti Mingguan Membersihkan Sampah Di Lingkungan Bersama Masyarakat

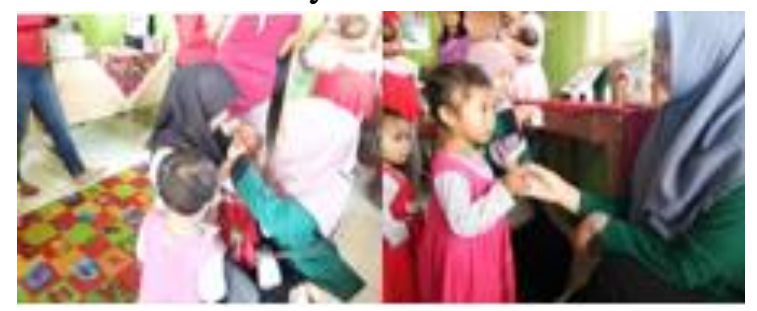

b. Posyandu Balita
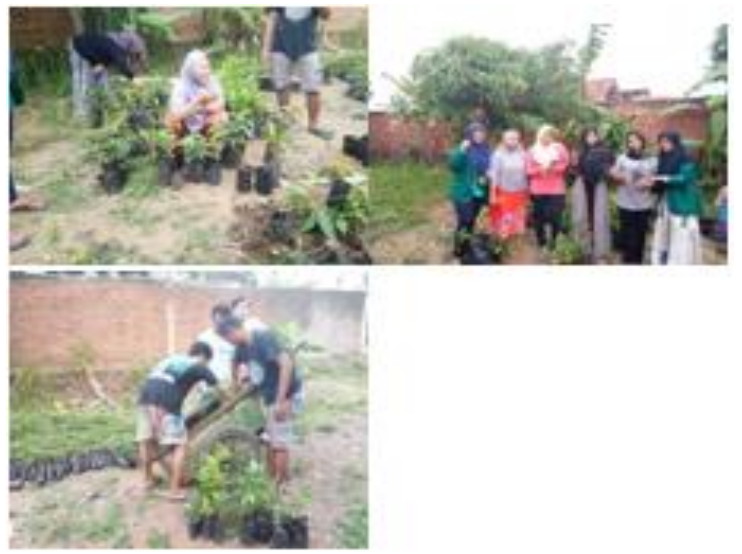

c. Penanaman Pohon Untuk Penghijauan Lingkungan

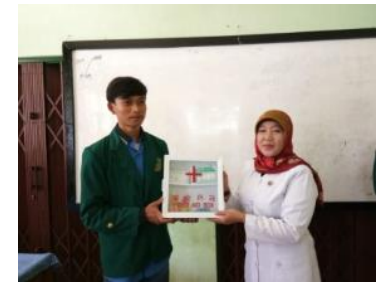

d. Pembentukan Unit Kesehatan Siswa
Bidang Ekonomi
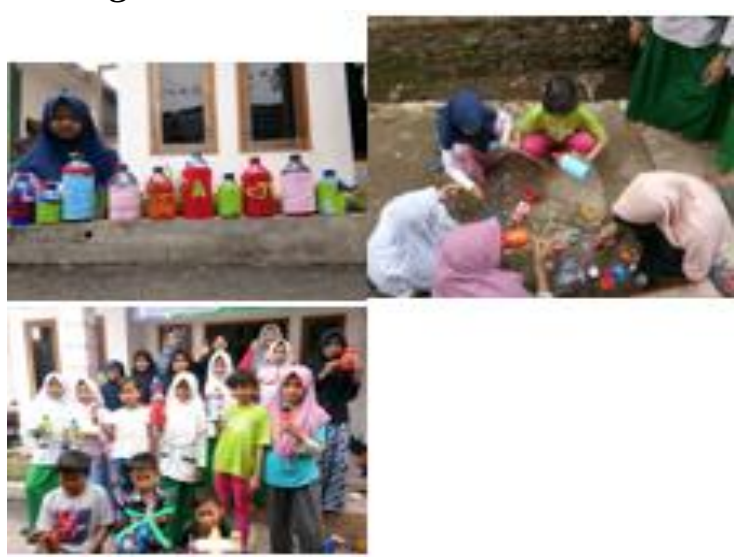

a. Penyuluhan Pemanfaatan Sampah Pada Anak-Anak (Ekonomi Kreatif), dan Praktik Ekonomi Kreatif Bersama Anak-Anak.

\section{Bidang Hukum dan/ Kemasyarakatan}

a. Penyuluhan Penggerakan Karang Taruna; serta Pembentukkan dan/ Pengorganisasian Karang Taruna

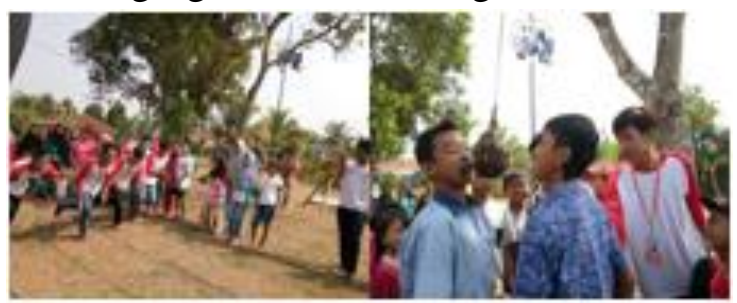

b. Perayaan Hut RI ke -73 .

\section{Program Tambahan}

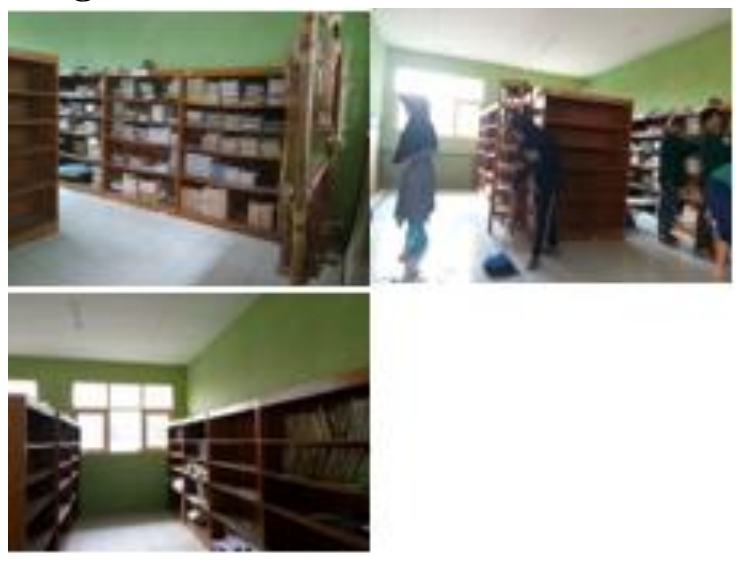

a. Penataan Perpustakaan 


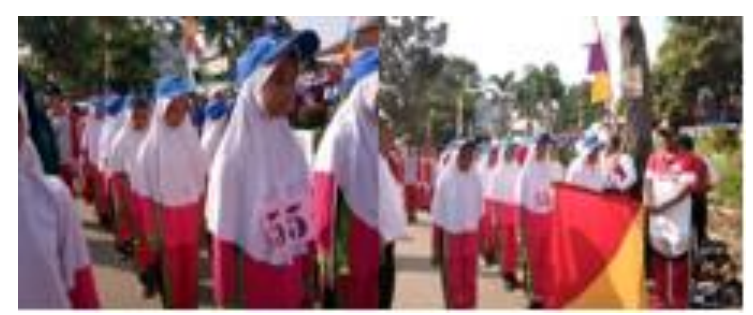

b. Lomba Gerak Jalan Se-Kecamatan Cibungbulang

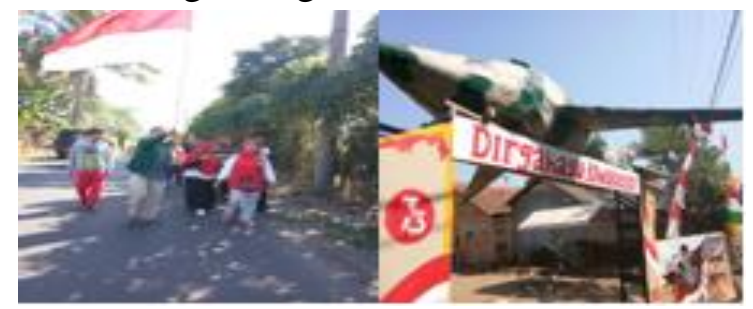

c. Festival Jalan Sehat Se-Desa Cemplang

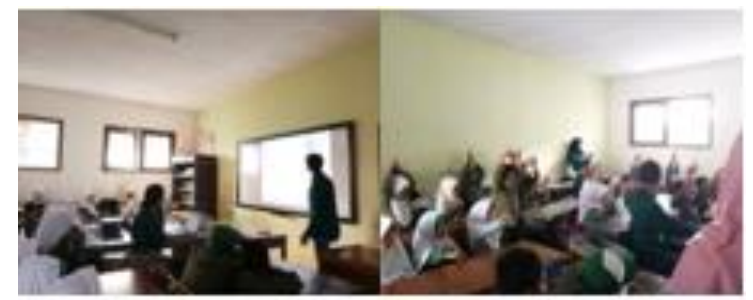

d. PHBS (Perilaku Hidup Bersih dan Sehat)

\section{KESIMPULAN}

Berdasarkan proses dan hasil kegiatan $\mathrm{KKN}$, maka dapat disimpulkan sebagai berikut :

a. Siswa/I Sekolah Dasar mulai memahami pentingnya menjaga lingkungan dan mendapat pengalaman serta wawasan memanfaatkan sampah dan cara memilah sampah.

b. Siswa/I Madrasah Ibtidaiyah mendapatkan wawasan dan pengalaman bercocok tanam.

c. Sekolah Dasar dan Madrasah Ibtidaiyah menjadi lebih bersih dan hijau.

d. Anak-anak yang mengikuti bimbingan belajar mulai dapat berhitung dengan cepat dan mengenal berbagai kata dalam bahasa inggris. e. Program pengajian orang tua dan remaja berjalan dengan baik sehingga medukung kegiatan pemakmuran masjid.

f. Anak-anak mendapatkan wawasan keagamaan dan mempelancar baca tulis Al-Qur'an.

g. Masyarakat memahami pentingnya kebersihan dan kesehatan

h. Lingkungan menjadi lebih besih dan sehat, serta lingkungan menjadi lebih asri dengan adanya penghijauan.

i. Meningkatkan dan/menumbuhkan perilaku hidup sehat dalam hal mencuci tangan.

j. Anak-anak menjadi lebih kreatif dalam memanfaatkan sampah

k. Terbentuknya karang taruna, terjalinnya silahturahmi antarwarga dengan lebih baik.

1. Perpustakaan menjadi lebih bersih dan rapi

\section{SARAN}

Untuk mengoptimalkan potensi sumber daya alam dengan upaya meningkatkan kualitas sumber daya manusia berbasis kepedulian lingkungan, perlu mendapat dukungan dari pemerintah daerah yang memiliki kewenangan di daerah tersebut, serta menjalin kerjasama yang baik antar masyarakat dan pemerintahan. Beberapa upaya yang dapat dilaksanakan sebagai suatu rekomendasi dari kami sebagai berikut :

1. Dalam bidang pendidikan, keehatan, dan kebersihan pemerintah perlu dapat memfailitasi dengan baik.

2. Dalam bidang ekonomi maupun hukum dan/ kemasyarakatan pemerintah perlu mendorong kegiatan ekonomi kreatif. 
3. Pemerintah perlu mendukung secara positif kegiatan pengaktifan karang taruna.

4. Pemerintah dapat menyempurnakan atau melanjutkan program Mahasiswa KKN yang dilaksanakan.

\section{REFERENSI}

Akhtar,Hanif. 2014. Peran Sikap Dalam memediasi pengaruh Pengetahuan Terhadap Perilaku Minimasasi Sampah Pada Masyarakat Terban, Yogyakarta. Jurnal Manusia dan Lingkungan, Vol.XXI, No.3 November

2014.https://scholar.google.co.id/schol ar?hl=id\&as_sdt=0\%2C5\&as_vis $=1 \& q$ $=$ peduli+lingkungan+pada+masyaraka t\&oq=peduli+lingkungan+pada+masy\# $d=g s \_q a b s \& p=\& u=\% 23 p \% 3 D U F H I q p$ MU5EYJ. Diunduh pada 9 September 2018.

LPPM. 2018. Petunjuk Pelaksanaan KKN Tematik Terintergrasi 2018 Universitas Ibn Khaldun Bogor. Bogor : UIKA PRESS.

Profil Desa Cemplang Tahun 2017 Kecamatan Cibungbulang Kabupaten Bogor. (Tidak Diterbitkan).

Sugiyono. 2016. Metode Penelitian Kuantitatif, Kualitatif, dan $R \& D$. Bandung:ALFABETA.

Sumber Daya Alam. (Online). https://id.wikipedia.org/wiki/Sumber _daya_alam. (diakses 9 September 2018).

Sumber Daya Manusia. (Online). https://id.wikipedia.org/wiki/Sumber _daya_manusia. (diakses 9

September 2018) 